Secondary publication on the edoc server of the Humboldt-Universität zu Berlin

https://doi.org/10.18452/21593

First published as:

Leslie Quitzow, Weert Canzler, Philipp Grundmann, Markus Leibenath, Timothy Moss, Tilmann Rave (2016) The German Energiewende - What's Happening? Introducing the Special Issue. Utilities Policy 41

(August): 163-171. doi.org/10.1016/j.jup.2016.03.002

This accepted manuscript version of the article stated above is licensed under a Creative Commons Attribution-NonCommercial-NoDerivatives 4.0 International License (CC BY-NC-ND 4.0) https://creativecommons.org/licenses/by-nc-nd/4.0/

\title{
The German Energiewende - What's Happening? Introducing the Special Issue
}

Leslie Quitzow, Weert Canzler, Philipp Grundmann, Markus Leibenath, Timothy Moss, Tilmann Rave

\section{Introduction}

As one of the world's most ambitious and comprehensive national energy transition initiatives, the German Energiewende is attracting massive attention in policy and research circles. Opinions range from admiration to admonition, with advocates hailing the Energiewende as a model for emulation and critics dismissing it as over-costly and illusionary. There is clearly an urgent need to provide grounded insight into how Germany's energy transition, nearly five years on from the nuclear exit strategy, is playing out in practice and what policy implications this has for comparable initiatives elsewhere. The special issue brings together papers from leading scholars in Germany to analyse how the Energiewende has translated from policy to practice since the German government's policy U-turn in 2011. Moreover, the special issue dedicates detailed attention to the causes and effects of various policy amendments that have been implemented since 2011, which have decidedly changed the character of Germany's Energiewende on the ground. The papers each address the complex and highly dynamic process of Germany's energy transition from the perspective of one issue critical to implementation. These issues include: costs and funding, contestation and conflict resolution, regional diversity and disparities, and new modes of governance. By critically reflecting the struggles and conflicts imminent to the transition process and emphasizing the 
importance of sub-national actors to national transition initiatives, the special issue shifts the focus of the overall debate towards questions of governance and beyond questions of technological feasibility. It compiles research insights from a wide range of scientific disciplines, brought together by members of the Leibniz Research Alliance on Energy Transitions from which the papers are drawn. The Leibniz Research Alliance on Energy Transitions is an interdisciplinary research network of independent German research institutes that was set up in 2013 to generate knowledge with which to accelerate Germany's Energiewende in particular, and energy transitions in general. The Alliance has set out a research agenda for interdisciplinary work focusing on three core challenges confronting the Energiewende, conceived as arenas of debate between the often conflicting priorities of

- Centralized and decentralized systems,

- Public and private interests and

- Global and local effects.

These core challenges provide the framework for the discussion of the articles presented in this volume. Section II gives a brief overview of how Germany's Energiewende evolved in the years leading up to the nuclear phase out in 2011. It is followed by a synopsis of international responses to the German Energiewende in media and academic literature, which is presented in Section III. Against this backdrop, Section IV summarizes and discusses the articles in relation to the three core challenges identified above. Section $V$ provides an outlook for further research on the topic.

\section{Germany's Energiewende - more than post-Fukushima policy}

The Energiewende is framed nationally by two key policy documents, namely the Renewable Energy Act (REA) and the Federal Energy Concept. These two documents state that Germany's nuclear power plants will be phased out within the next 10 years, and that its current energy system - which still depends largely on nuclear power, oil, coal and gas - will be transformed into an energy system strongly reliant on renewable energies by the year 2050 (BMWi and BMU, 2010). The main sources of energy will then be wind power, solar energy, hydropower, biomass and geothermal energy. In particular, the German Energy Concept sets out medium to long-term targets for the reduction of energy use and greenhouse gas emissions as well as goals for increasing energy efficiency (BMWi and BMU, 2010). Among its main aims are a $50 \%$ reduction of primary energy use by 2050 (compared to 1990 levels) and an $80 \%$ reduction of greenhouse gas emissions by the same year (compared to 2008 levels). To reach these goals, the German government aims at steadily increasing the share of renewables in overall final energy consumption to $60 \%$ by 2050 . Special importance is placed on increasing the share of renewably generated electricity consumption to $80 \%$ by the year 2050 . The goals set out in the Energy Concept are complemented by the decision to phase out nuclear energy production by 2022, which was taken suddenly and unexpectedly by the Merkel administration following the Fukushima nuclear disaster in 2011. Given the relatively low levels of emissions from nuclear power generation in comparison to fossil-fuel based generation from sources such as coal, this decision puts heightened pressure on the environmental targets set out in the Energy Concept.

However, the reasons behind Germany's radical policy decisions are not climate protection and environmental sustainability alone, but also reduction of energy imports, high-tech development and 
economic growth. By diversifying its energy sources, the country aims at minimizing its dependence on external energy imports and getting a head start on research, development and deployment of future energy systems in order to secure its share on a growing global market for renewable energy technologies. Regional and local governments, in particular, are embracing these economic targets. They are increasingly relying on renewable energy technologies as a means to strengthen local value creation and secure jobs (see for example Leibenath et al, and Rave and Götzke, this issue).

Taken together, the goals set out by the German government pose enormous technical, economic, and societal challenges not only at the national, but at all administrative levels. They require substantial changes and innumerable innovations in energy supply technologies, energy networks, and energy management practices (Kemfert, 2013). The greatest technical challenges currently confronting the German Energiewende include the reorganization of energy distribution networks (Zeng et al., 2013), the development of novel energy storage technologies (Ausfelder et al., 2015; Pape et al., 2014), and their integration into energy grids (Appelrath, Kagermann and Mayer, 2012). At the same time, the translation of Energiewende targets into local practice is also transforming long established social and economic structures. As the research presented in this special issue reveals, the Energiewende is challenging local and regional governance arrangements, institutional structures, market logics, spatial planning practices, and many more. A purely technological approach will therefore not suffice to make the Energiewende a success (Ethics Commission for a Safe Energy Supply, 2011).

\section{a) Objectives and instruments since the $1980 \mathrm{~s}$}

Although the German Energiewende is commonly associated with the country's post-Fukushima national energy policies, it is neither a recent, nor a purely government-led phenomenon. The nuclear phase-out of 2011 marks only the latest in a series of policy initiatives in response to a long history of nuclear skepticism, growing awareness of peak oil and its implications, and concern over climate change and sustainable development issues that have been prevalent in the country for decades, not only in terms of energy.

In fact, concerned citizens and committed scientists launched a public discourse on renewable energies as early as the 1970s. Their debate started as a marginal phenomenon, but gained momentum and attention after an initial, influential publication emerged in 1980, entitled "Energiewende - Growth and Prosperity without Oil and Uranium" (Krause, Bossel and Müller-Reißmann, 1980). Apart from coining the term Energiewende, the authors suggested some of the key instruments for promoting renewable energies that still constitute Germany's energy policy today, such as priority grid access and long-term guaranteed feedin tariffs to provide a stable investment framework for expansion. By the time of the book's publication, renewable energy issues were already firmly embedded both in an ecological movement, organizing local protest against nuclear energy, and a growing community of local entrepreneurs, experimenting with unconventional and small-scale wind and solar energy technologies as well as with concepts to save energy (Scheer, 2007). In many ways, the rise of renewable energy technologies in Germany is therefore founded upon locally rooted, community-driven, and ecologically inspired political activism (Morris, 2014). 
The ecological and anti-nuclear movements certainly set the pace for the growing importance of environmental issues in national level politics and formed the breeding ground for the first renewable energy diffusion policies, which were passed by the German government in the early 1990s. But even though the "1000-roofs-program" for photovoltaic power (PV) and the first feed-in tariff for wind, PV, hydropower and certain bio-based energies both stimulated investments in (some) renewable energies, their impact was still relatively marginal. This changed when the Renewable Energy Act (REA) was passed in the year 2000. The REA provided a more stable policy framework, particularly for the relatively expensive PV technologies. In contrast to the first feed-in tariff, it was now decoupled from the electricity price and based on the real generation costs of the technology (with additional differentiation within each technology). Moreover, feed-in tariffs were granted over a 20 -year period. The REA now provided a strong incentive for growth across most of the various renewable technologies, particularly in the second half of the 2000s.

The success of these market incentives between 2004 and 2012, in terms of the investments in renewable energy infrastructure, exceeded all expectations and predictions. It is primarily in response to the unexpected dynamism of the renewable energy sector that the instruments have been adjusted, with various amendments to the REA, and specifically the feed-in tariffs. Following huge demand for PV, the international price for solar modules and other PV components dropped sharply in the mid-2000s without the feed-in tariffs being adjusted quickly enough, leading to substantial excess returns for plant operators. For biomass, concerns emerged about undesirable side-effects, such as rising food prices. The more recent amendments to the REA in 2012 and 2014 have placed more emphasis on market and system integration of renewable energies whilst restraining the growth rates of expansion particularly for biomass and rooftop PV. To allow for better grid integration of renewables additional quantity controls ("expansion corridors") have been integrated into the price-oriented feed-in system. Moreover, some market-oriented elements have been introduced into the REA. Plant operators (or intermediaries) are now obliged to submit power produced directly to the electricity market to stimulate a more demand-oriented feed-in of renewable energies. Also, and in accordance with EU regulations, renewable energies are no longer being promoted solely with fixed, regulated prices, but increasingly with market-based instruments such as technology-specific, volume-based auctions.

\section{b) Achievements to date}

There is no doubt that the REA, as a pillar of the Energiewende, has been very effective in raising the share of renewable energies in the power mix (Hirschhausen, 2014). This, however, has always been only one of the objectives of Germany's energy transition. Not all of these objectives are consistent with each other, not all of them will easily be achieved and some are likely to involve negative side-effects and costs which are already provoking heated debate. In the following, we provide a brief and non-comprehensive overview of the achievements and challenges of the Energiewende so far:

- Renewable energies: So far, renewable energies have mostly thrived in the electricity sector, with the share of renewable energies in gross power consumption rising to nearly 33\% in 2015 (Agora Energiewende, 2016). By contrast, in the heat and the transport sectors, the share of renewables remains comparatively low. The share of renewable energies in final consumption of heating (and 
cooling) and transport amounts to only around $13 \%$ and $6 \%$, respectively (BMWi, 2015). Moreover, there has been no marked increase in energy efficiency during the Energiewende.

- $\mathrm{CO}_{2}$-emissions: $\mathrm{CO}_{2}$-emissions have dropped slightly since 2010 , but a consistent downward trend is not on the horizon. ${ }^{1}$ Despite a reduction on the use of coal for electricity generation in absolute terms (minus 14 TWh), it still remains on a high overall level (Agora Energiewende, 2016) and its share in the energy mix has even increased in relative terms. Regarding climate policy, the effect of more renewable energies is currently paradoxical: The share of coal which is most harmful to the climate increased at the expense of natural gas as a complement to renewable energies. This results mainly from the mechanism of merit order at the power market and the weak $\mathrm{CO}_{2}$ reduction signals from the EU emissions trading system. Under these conditions, (new) gas turbines are not competitive with coal-fired power plants whose costs have long since been recovered.

- Green business and organizational forms: The REA has provided a massive business incentive for small-scale private energy entrepreneurs. By the year 2014, nearly half of renewable energy in Germany was produced by private persons, energy cooperatives and farmers (trend:research and Leuphana Universität Lüneburg, 2013). About 1.2 million PV plants and more than 4,000 wind turbines are owned by private persons or civic organizations such as cooperatives.

- Employment effects: Direct and indirect gross employment effects of setting up renewable energy capacities (plant/component production, installation, maintenance etc.) have been significant. Gross employment in renewables increased from 160,000 in 2004 to around 370,000 in 2013, with a slight decrease more recently (Lehr et al., 2015). At the same time, there have been structural changes within the energy industry in response to the rising cost of electricity. In net terms, employment effects are therefore less clear. Critics argue that higher power prices have had negative effects on employment, crowding-out conventional energy sources, whilst import substitution (e.g. of Chinese PV modules) has undermined the national market for renewable technology producers. Fears of rising energy costs prompting the out-migration of firms from Germany appear unfounded, however, not least thanks to the rebates for energy intensive industries permitted in the REA (Rosenkranz, Fücks and Landgrebe, 2014).

- Energy prices and costs: The Energiewende has undeniably resulted in a sharp increase in electricity costs, especially for private households and small and medium-sized firms that do not benefit from special rebates. For a three-person household the cost of electricity has doubled since 2000. In particular, the share of taxes and levies has risen from below $40 \%$ to above $50 \%$ (BDEW, 2015). Negative distributional effects are also an issue of concern. The $10 \%$ of households with the lowest income pay about $1 \%$ of their available income to finance the REA, whereas the same share among the households with the highest income is only 0,17\% (Techert, Niehues and Bardt, 2012). Yet, based on purchasing power and in the long term the cost burden on households and firms has changed little. For example, calculations suggest that the time at work needed to produce 200 $\mathrm{kWh}$ of power for households has remained almost constant in the last two decades and has even decreased by two thirds relative to 1960 (Rosenkranz, Fücks and Landgrebe, 2014).

\footnotetext{
${ }^{1}$ See http://www.umweltbundesamt.de/daten/klimawandel/treibhausgas-emissionen-in-deutschland.
} 
- Accumulated payment obligations and negative incentives: Accumulated payments from the REA surcharge will have to be carried over to the future. Proposals to reorganize the payment legacies (e.g. via a redemption fund) have not been well received (Töpfer and Bachmann, 2013). Moreover, it remains difficult to make production-oriented feed-in tariffs or premiums compatible with the needs of a changing energy system. As already indicated, mechanisms need to be developed to allow for a smoother and more cost-effective balancing of energy supply and energy demand and to support the functionality of the power grid (Nordensvärd and Urban, 2015).

\section{The Energiewende in international debates}

Germany's Energiewende has evoked a huge variety of responses in international research and policy circles, from positive to negative. While supporters perceive Germany's energy transition as a role model and worthwhile investment in a sustainable future, many voices strongly criticize the Energiewende as a highly risky and improbable endeavor, a climate killer, an economic disaster, a burden on consumers and industry, or as technologically outdated.

Respect is expressed for the comprehensiveness of Germany's energy transition. Some hail it as a pioneering step toward environmental protection that other industrialized nations should follow (Friedman, 2015). Others state that "even partial transformation of such a big industrial economy to a lower carbon system would be remarkable" (Buchan, 2012, p. 33). Part of this achievement is attributed to the feed-in-tariff. There is overall consensus that the REA has been hugely effective at disseminating renewable energy technologies while simultaneously reducing their cost (International Energy Agency, 2013), even though this is not entirely true for bioenergy. Germany is given credit for spurring supply and demand of renewable energy technologies on a global scale. Moreover, international observers claim that the rapid proliferation of renewable energies has fostered innovation and created jobs in the environmental industry and related sectors in and outside the country (Borden and Stonington, 2014; Buchan, 2012). Many therefore believe that in the long term Germay can benefit from increased R\&D on a worldwide market for renewable energy technologies, and that the Energiewende could thus become an important boost for Germany's economy (Birnbaum, 2012; Buchan, 2012). This is underscored by the strong backing of the Energiewende by the German public. The broad base of private investments into renewable energy technologies and widespread citizen participation are seen as one of most unique characteristics and greatest achievements of Germany's energy transition so far (Borden and Stonington, 2014; Buchan, 2012).

However, the challenges still confronting the Energiewende are enormous and criticism abounds. Major weaknesses attributed to the transition process in and outside Germany include the continuing struggle to limit costs, ambiguous environmental outcomes, numerous remaining technical constraints and a series of construction delays that have stalled necessary infrastructural developments. Delays in extending the transmission grid and thereby linking the wind-rich North with the energy-hungry South are frequently highlighted as an important bottleneck in the current transition process. Moreover, some question whether Germany will be able to develop the necessary grid technology quickly enough to take up intermittent renewable energy flows, maintain security of supply and avoid grid congestion (Borden and Stonington, 2014). In the absence of this technology, critics have also pointed to the irony of Germany having to rely on imports of neighboring countries' nuclear energy. In spite of certain advances, sceptics 
are still reluctant to believe that Germany will be able to meet its ambitious environmental and energy reduction targets while at the same time phasing out nuclear generation (Rhys, 2013). This is especially attributed to the strong market presence of the heavily polluting coal industry (Bruninx et al., 2013), but also seen in light of the weakness of the European Emissions Trading Scheme (ETS) (Bruninx et al., 2013; Rhys, 2013). By far the biggest question marks, however, are related to costs. There has been harsh criticism of the burden that the cost of the feed-in tariff is putting on consumers and industry (Dempsey, 2012; Eddy and Reed, 2013; Nicola, 2013, 2015). Forbes magazine even polemically speaks of a "green energy disaster" brought about by "command economists" (Rich, 2013).

Global coverage on the Energiewende has, interestingly, gone through various phases. Directly after Merkel's policy turnaround in 2011 international reception of the Energiewende was highly expectant but also wary. Environmentalist observers were keen to understand whether and how Germany would make the energy transition work, not least due to the boldness and the comprehensiveness of the endeavor. Two years into the process, criticism of the Energiewende grew sharply due to an observed explosion of costs, unfavorable environmental developments and growing doubt that Germany could master these challenges in the midst of the European financial crisis. Two more years and one policy amendment later, the reception is growing more positive again. Costs are perceived to be stabilizing, the share of renewables has obviously grown and advances toward achieving the climate targets are acknowledged. Currently, it seems that Germany is perceived to be back on track. Nevertheless, there is acute awareness of the remaining challenges, the uncertainty of the outcomes and the sheer magnitude of the overall endeavor.

All in all, international coverage has focused on a narrow set of aspects that characterize Germany's clean energy experiment. These international discussions highlight the changes occurring at the national level, mostly analyzing challenges and opportunities related to policy, the environment, technology and costs. However, few international analyses have dealt with the details of local implementation or, more generally, with the societal changes occurring in the wake of Germany's Energiewende and their expressions at the level of local communities, towns and regions (for exceptions, see Negro and Hekkert, 2008; Nordensvärd and Urban, 2015). Few accounts from outside Germany have scrutinized the great societal challenge Germany faces due to the Energiewende, or the social and political shifts occurring as a result, for example through large-scale community ownership. There is a burgeoning literature in German on how the Energiewende is playing out in practice, written primarily from a national perspective, but this work is rarely reflected or referenced in English-language academia. Only very recently have researchers within Germany begun publishing their findings in international journals (e.g. Jenssen et al., 2014; Moss et al., 2014; Sagebiel et al., 2014; Busch and McCormick 2014). This special issue sets out to close this knowledge gap by providing an inside view of the current situation in Germany and reflecting on the stateof-the-art debate there for an international audience.

\section{Core themes of the special issue}

The articles presented in this special issue span a great variety of academic debates, theoretical perspectives and analytical approaches, providing a broad cross-section of relevant issues currently confronting the German Energiewende. They cover controversies over energy economics with an eye to the European context (Neuhoff et al), explore questions of diverging regional developments (Rave et al; Appel et al; Roehring et al), analyze the foundations of emerging value chains (Grundmann), illustrate cases 
of local community-building and conflict (Blanchet et al; Leibenath et al; Reusswig et al), and link questions of energy to visions of future mobility transitions (Wittowsky et al). They represent diverse disciplinary approaches reflecting the institutional diversity of the Leibniz Research Alliance on Energy Transitions, as well as the wide-ranging societal impact of Germany's Energiewende. Furthermore, the findings gathered in this issue apply a broad variety of research methodologies, ranging from mathematical models to indepth empirical case studies. The articles are, therefore, well placed to reveal the heterogeneity of impacts and responses to three core challenges currently confronting the Energiewende.

\section{a) From centralized to decentralized energy systems}

The traditionally centralized and monopolistic structure of Germany's energy sector is currently being replaced by much more decentralized and diverse renewable energy systems. This creates tensions and conflicts that are "inherent to the transition process", as Reusswig et al state in this issue. To what degree this multi-faceted decentralization process will continue and with what ecological, spatial, technical and social effects is currently unclear. Many facets of decentralization are reflected in the articles of Blanchet et al., Leibenath et al, Reusswig et al and Grundmann, all of which employ a qualitative research methodology. Other papers look at decentralization more from a quantitative or top-down perspective: Rave and Goetzke study heterogeneous incentives and interests for wind energy expansion across various regions (understood as German states, county types or counties). Appel et al focus on bioenergy and the effect of the REA on farm size, agricultural structure and related markets.

The upsurge of grassroots energy initiatives is diversifying, if not "democratizing", Germany's energy sector (Blanchet et al., this issue). At the same time, public participation in the energy sector is also a breeding ground for local energy-related opposition, for example against the allocation of land for wind power plants, the diffusion of maize monocultures, the displacement of agricultural crop production for food, the emergence of factory farms to feed biogas plants and the extension of the transmission grid from the windy north to the energy hungry south (see Leibenath et al; Reusswig et al; Appel et al, this issue). Throughout the country, both the extension of the transmission grid and the proliferation of wind energy farms have become an especially common source of local opposition and conflict, posing a serious threat to further infrastructural developments. This is interesting given the fact that studies project the relatively cost-efficient onshore wind energy becoming a major pillar of Germany's future energy system (e.g. SRU, 2011). Against this background, the articles by Leibenath et al. and Reusswig et al. trace the specific dynamics of wind energy conflicts in different German communities and explain the conditions for their development. While Leibenath et al. critically discuss the effects and limitations of participatory planning instruments in dealing with energy-related conflicts, Reusswig et al. focus on the formation of social protest. Both articles show that citizen engagement in energy-related decision-making does not necessarily lead to compromise, but can instead lead to standstill. In Saxony, where opposition against wind energy is allegedly stronger than anywhere else in Germany, Leibenath et al explain that contradictory state-level politics are part of the problem. By embracing ambitious wind energy targets on the one hand, but defending the heavily polluting lignite industry with its high levels of employment on the other, the state government has created an uncertain environment for local political and economic practice. Due to inconsistent and insufficient communication about the possible benefits of wind energy generation, opposition remains stable in spite of participatory planning processes. Rising public engagement in the energy sector has also resulted in increasing popular knowledge of energy related 
concerns. Reusswig et al highlight the rising public awareness for energy issues and resulting professionalism with which local protest groups engage in wind energy opposition. In contrast to Leibenath et al they examine a case where resistance unexpectedly develops in an otherwise favorable environment. The authors show how a relatively small group of opponents is able to mobilize a critical mass of followers not least due to their comprehensive knowledge of the subject matter and resulting argumentative power.

Through decentralization, an increasing number of well-informed players hold stakes in the German energy system. As a result, local and regional energy governance regimes are changing, and new alliances between actors are forming (see Blanchet et al; Röhring et al, this issue). Blanchet et al study the blurring boundaries between grassroots energy initiatives and established stakeholders such as local governments and utility companies, as well as their increased interaction in utility policy and politics. Their research follows the wave of remunicipalization that has occurred in Germany over recent years and explains the impact that different kinds of grassroots energy initiatives have had on this process. While Blanchet et al focus their analysis on four urban case studies, Röhring et al point out that the decentralization process has in fact resulted in an overall ruralization of energy production. It has thus increased the importance of local and regional planning instruments for governing the spatial allocation of renewable energy plants. By contrasting the development of two neighboring regions, the authors show that federal energy policy has had a very diverse impact on different areas of the country. Among others, they show that this is related to the different historical legacies of former East and former West German territories, particularly regarding farm sizes, levels of civil society organization and regional planning cultures. Although many regions are far surpassing renewable energy production targets, the authors demonstrate that attitudes towards the Energiewende differ considerably. They show that acceptance of renewable energy technologies is higher where ownership lies in the hands of local communities, while feelings of resentment for the Energiewende predominate where levels of citizen participation are lower and large multi-national companies dominate renewable energy supply. Their article reminds us that decentralization has not only mobilized small-scale private engagement, but has also attracted large corporate investments into solar parks, bioenergy farms and onshore wind parks.

Further effects of large-scale investments are especially visible in the case of bioenergy. The federal feedin tariff for biogas provides investment incentives for individual farms and farming communities, which are aimed at, inter alia, supporting structural adjustment, promoting community life and fostering local identity in rural environments (Grundmann, this issue). As Appel et al show, however, the tariff has also had quite a controversial impact on local farm structures, rural land markets and agricultural production (Appel et al, this issue). At the individual level, Appel et al demonstrate that only large and financially potent farms have been able to benefit from biogas investments in the long run, while smaller, less efficient farms have been virtually displaced. At the regional level, these large-scale investments have resulted in increased land prices, an overall intensification of land use, and less food crop production. In effect, decentralized bioenergy production has indeed contributed to Germany's energy-related goals, but many affected regions have also undergone structural changes of questionable quality. Again, rural communities can best collectively benefit from bioenergy production if they develop appropriate responses or coping strategies in the face of changing federal energy policies. This depends on qualities such as strong leadership, mutual trust and citizen participation (Grundmann, this issue). 
Together, the articles point to a range of dissonances and unforeseen developments that have emerged at the local and regional levels due to the shift from centralized towards more decentralized energy production in Germany. They show that federal energy policies have resulted in a strong diversification not only of energy sources, but also of individual and collective responses to rapidly changing energy landscapes.

\section{b) Diverging public and private interests}

Although a broad public consensus still backs the Energiewende in general, we note that conflicts of interest arise at the local level over implementation. These conflicts cannot be reduced to a straightforward dispute between the public interest in a more sustainable energy system and more particularistic interests of individual actors. Public interests in energy provision are themselves manifold and can be contradictory. As experiences in Germany are revealing, they reach beyond the familiar trias of security of supply, affordability and environmental sustainability to include collective issues such as local regeneration, regional identity and non-profit provision (Kunze, 2012; Moss et al., 2013). Local conflicts often arise over perceived injustices to individual or single-community concerns, such as noise pollution, loss of tourism or damage to landscape qualities, as in the case of wind power (Leibenath et al). At the same time, they can also arise over perceived injustices over conflicting public interests, such as nature conservation, biodiversity, climate protection or health (Reusswig et al). Although especially wind plants are increasingly perceived as oversized, ugly and noisy disturbances in many German regions, Reusswig et al show that so-called 'NIMBYism' is therefore an insufficient explanation for local protest (Reusswig et al). Instead, opposing parties equally claim important public ecological concerns. Moreover, Leibenath et al show that conflicts can also arise over rural-urban disparities. With increasingly decentralized energy production, rural communities tend to feel disproportionately burdened by the energy demands of cities. Leibenath et al bring to light a perceived discrepancy between the interests of urban "left-wing, upperclass intellectuals" and the "environmental disfigurement and negative health effects" from which rural communities claim to suffer (Leibenath et al, this issue). Moreover, the structural effects of the Energiewende on agricultural regions have resulted in changing perceptions of the public costs and benefits of increased bioenergy production. In particular, the intensification of land use and the changing structure of agricultural production (especially for maize) are increasingly seen as competition for food production. This has effectively led to a number of amendments to the REA (see Appel et $a$ )).

The rapidly changing policy environment that has accompanied the Energiewende also poses a great challenge for local entrepeneurs: they are increasingly forced to make business decisions under conditions of considerable uncertainty. Often, these are delicate decisions that rely on the participation of a whole community, as in the case of communal heating grids (Grundmann). The process of weighing economic, environmental, public and private interests and reaching collective decisions depends heavily on governance capabilities and choices. These can be deeply affected by the socio-economic history of a region (Röhring et al), the ability of actors to forge bonds across the incumbent-challenger dichotomy (Blanchet et al), as well as the existence (or not) of strong leadership (Reusswig et al; Grundmann et al) and well-established community-led organizations (Röhring et al; Grundmann). The negotiation of interests can be a long and tedious process, especially if political will is lacking. Wittowsky and Canzler 
remind us of this by pointing to one of the biggest blind-spots of the German Energiewende, namely the mobilty sector. Although transport is responsible for approximately one third of energy consumption in Germany, it has been largely neglected in public debates so far (Wittowsky and Canzler, this issue). In the authors' opinion the current mobility 'lock-in' is due to a long list of conflicting interests, not least between individual convenience and collective environmental concerns, but also between such practical realities as the public funding mechanisms for public transportation networks and the governance of flexible carsharing fleets.

In sum, the articles show that a complex set of public and private interests are currently being negotiated at local and regional levels that are distinctly and fundamentally shaping energy transition processes across the country.

\section{c) Calibrating global and local effects}

In their appeal to combine energy and mobility transitions, Wittowsky and Canzler remind us that the Energiewende is not an end in itself, but a contribution to the global challenges of increasing environmental sustainability and mitigating climate change. They convincingly argue that these goals cannot be achieved without significant changes to current mobility patterns (Wittowsky and Canzler, this issue). The authors put the Energiewende into perspective by pointing out how disillusioning both German and global mobility trends are in environmental terms. While in Germany individual motorized traffic rates are stagnating, global car ownership is projected to increase by approx. 50\% by 2030 (Wittowsky and Canzler, this issue). Confronting these alarming predictions, their article argues that current energy-related efforts are at best negligible if the transport sector continues to be ignored. Their contribution should thus be read as an urgent plea to think energy and mobility transitions together. In this sense, it also shifts attention from the challenges of increasing renewable energy production to the challenges of reducing energy consumption. Moreover, it effectively calls our attention to the first steps each one of us can make in order to shape new, low-carbon mobility routines, including car-sharing, cycling and multi-modal travelling. However, it also reminds us of the tremendous behavioral, organizational and regulatory obstacles that stand in the way of comprehensive mobility transitions (Wittowsky and Canzler, this issue).

The magnitude of cultural, organizational and especially regulatory challenges that confront energy transitions is perhaps most tangible in processes of multi-level governance and coordination. This holds true within Germany, but even more so within the European Union. In Germany, lack of coordination between energy policies at different levels of government has resulted in a wide variety of energy targets across different federal states. In fact, the states are free to set their own renewable energy targets more or less independently of federal energy policy. As Rave and Götzke point out, this has led to the absurd situation that "the federal government aims to achieve a $35 \%$ share of renewable electricity consumption by 2020 [...], whereas the aggregated goals of the states amount to between 50-55\%." (Rave and Götzke, this issue) Because neither the federal nor state-level energy policy frameworks define targets for the allocation or (until recently) amount of any specific generation technology, renewable energies have spread more or less uncontrolled across the country. In the case of wind, for example, Rave and Götzke show that generation plants have been erected as much due to labor markets as to environmental 
concerns (Rave and Götzke, this issue). The link to these and other - possibly diverging - 'local' development issues complicates the coordination of energy policies across German regions.

The German Energiewende is of course also embedded in the European policy and market context. Indeed, not only Germany, but the European Union itself and many of its member states have passed strategies to decarbonize their economies. Nevertheless, the integration of national energy policies and creation of an

"energy union" are still far from complete. The development of an internal energy market including common regulation is among the most intensely debated issues. Although power market integration is advancing (Neuhoff et al, this issue), important questions remain unresolved, for example regarding the harmonization of physical infrastructure, the establishment of joint rules for accounting, and the coordination of capacity mechanisms to ensure security of supply (Helm, 2014). Against this background, Neuhoff et al make a point of shifting their focus from the national to the European level in their discussion of different possible ways of organizing low-carbon power markets in the future. They focus on the question of how to secure stable electricity supply in a system that is increasingly based on fluctuating (renewable) inputs. Confronting this problem, most European countries have already installed so-called 'capacity mechanisms', i.e. reliably dispatchable generation capacities. The authors take an explicitly European standpoint in their argument for the establishment of coordinated, cross-border strategic reserves as an efficient and effective capacity mechanism, and as one pillar of a joint European energy transition (Neuhoff et al). A number of countries, including Finland, Sweden, Poland, the UK, and Belgium, already work with strategic reserves, and Germany has decided to follow suit (Neuhoff et al, this issue). Up to now, however, these mechanisms are designed and utilized exclusively within national borders. It remains to be seen whether and how different European energy markets, policies and traditions can be effectively coordinated in the future.

Together, these articles broaden our view of the German Energiewende by exploring the relationships and interdependencies between different levels of governance and implementation. They complement the very local focus of this volume by zooming out and showing that negotiations are not only taking place wtihin and between communities, but also between Germany and its neighboring countries.

\section{Outlook for future research}

The articles in this special issue provide an overview of how the German Energiewende is playing out in politics and practice at the regional and local level. They offer detailed insights into the various ways in which actor coalitions are changing, conflicts of interest are being negotiated, local communities are coping and new energy regions are developing. The special issue therefore widens the perspective from questions of national policies and instruments towards discourses and frames used in energy related conflicts, as well as the very diverse local struggles and controversies that have remained largely hidden from the international view. Moreover, some articles highlight the need to better understand the interlinkages of prominent national policies such as the feed-in tariff with other policies and incentives at various levels. For example, feed-in tariffs are an attractive (but not necessarily efficient) way to stimulate employment at the regional level. They also have important implications at the level of the energy system overall, as can be seen by the discussion about capacity markets. 
The articles reveal that the German Energiewende is much more than just developing renewable energy technologies, implementing a feed-in tariff, or containing costs. Instead, they direct our attention to forms and processes of public participation that have not sufficiently been addressed yet, as well as the complex and often diffuse and controversial social, political and economic impacts occurring beneath the surface of national energy policies. Clearly, many of these shifts are causing tension and conflict. They involve very personal fears, as in the case of NIMBYism, and also collective challenges, such as unequal levels of citizen involvement and the emergence of regional pockets of resignation or resentment. The articles indeed demonstrate that frustration with certain facets of the Energiewende is increasingly being vented in form of locally organized public protest. At the same time, this special issue also provides detailed insight into how communities and regions are embracing the transition process as an opportunity, for example to advance new strategic partnerships, to engage in new lines of businesses or to create jobs. If anything, they show that the Energiewende has resulted in high levels of public awareness for energy (and climate) issues, and in many creative forms of individual and collective participation in energy related activities. In sum, the research presented in this volume shows that understanding how and why the Energiewende is being interpreted, appropriated or resisted in local communities and across regions provides a valuable basis for understanding the complex dynamics that underlie its overall development, and can determine its success (or failure) in the long run. This special issue therefore argues powerfully that the local processes and diffuse effects of energy transitions deserve the same detailed attention that national and supra-national energy policies have received in the media and academic discourse so far.

Nevertheless, the articles also demonstrate the challenges faced when attempting to capture or even generalize the often diffuse impacts of a diversity of complex local energy transitions. Much of the social science contribution to the Energiewende to date is based on single-case studies. These are generating valuable new knowledge on the diversity of local and regional experiences, but how far these are exceptional or in any way representative of general trends is not yet known. There is, therefore, an urgent need for large- $\mathrm{N}$ comparative research of local and regional impacts of, and responses to, the Energiewende. It would also be valuable to explore how far lessons on implementing the energy transition are being learned and how specific policies, strategies or instruments are 'travelling', in adapted form, between locales or regions.

It is beyond the scope of this issue to treat all aspects of the Energiewende comprehensively. Most of the articles here deal with questions related to electricity from wind and bioenergy, and thus do not address a range of important research issues related, inter alia, to other sources of renewable energy (such as solar energy), energy storage, and energy efficiency. In these cases, too, sensitivity to local and regional differences can prove especially valuable. Other fruitful and necessary avenues for future research not covered in this issue include the interdependencies between electricity and other energy forms (such as heat) and how these are changing not only technically, but also in terms of institutional arrangements, regulatory frameworks, and actor constellations. This leads on to questions regarding the trade-offs inherent to energy transitions. Our special issue only briefly touches upon certain trade-offs over land use, which hint at the vast implications they might have on food production, particularly in international contexts. Similar questions could be extended to the nexus with other sectors and resources, such as water, and directed more explicitly toward issues of energy justice, not only from a local perspective, but also nationally and even globally. Furthermore, research on energy transitions should tackle certain blind 
spots largely absent from research agendas so far, especially in Germany, most notably questions of energy sufficiency, or the possibility of simply reducing levels of energy consumption, not through efficiency measures, but through abstention.

Overall, these various research avenues reflect the diversity and complexity of energy transition processes, and thus point to the necessity of integrating research from different disciplinary perspectives. Further, a long term perspective - for instance, via longitudinal analysis - is needed to better understand the implications of the Energiewende in Germany and energy transitions elsewhere. This special issue has compiled a selection of research concepts, methods and findings representing the early fruits of research conducted within the Leibniz Research Alliance on Energy Transitions. It is a core task of this group in the future to develop from this knowledge base a platform for long-term, interdisciplinary research on energy transitions in Germany and beyond.

\section{Reference list}

Agora Energiewende (2016) Die Energiewende im Stromsektor: Stand der Dinge. Rückblick auf die wesentlichen Entwicklungen sowie Ausblick auf 2016. Berlin.

Appelrath, H.-J., Kagermann, H. and Mayer, C. (2012) Future Energy Grid: Migrationspfade ins Internet der Energie. Berlin (acatech STUDIE).

Ausfelder, F., Beilmann, C., Bertau, M., Bräuninger, S., Heinzel, A., Hoer, R., Koch, W., Mahlendorf, F., Metzelthin, A., Peuckert, M., Plass, L., Räuchle, K., Reuter, M., Schaub, G., Schiebahn, S., Schwab, E., Schüth, F., Stolten, D., Teßmer, G., Wagemann, K. and Ziegahn, K.-F. (2015) 'Energiespeicherung als Element einer sicheren Energieversorgung', Chemie Ingenieur Technik, 87(1-2), pp. 17-89. doi: 10.1002/cite.201400183.

Birnbaum, M. (2012) 'Germany faces energy balancing act', The Washington Post, 23 August. Available at: https://www.washingtonpost.com/world/europe/germany-faces-energy-balancing-act/2012/08/23/ d3b82ddc-e979-11e1-936a-b801f1abab19_story.html (Accessed: 29 October 2015).

Borden, E. and Stonington, J. (2014) 'Germany's Energiewende', in Clark, W.W. (ed.) Global sustainable communities handbook: Green design technologies. Amsterdam: Butterworth-Heinemann an imprint of Elsevier, pp. 369-386.

Bruninx, K., Madzharov, D., Delarue, E. and D'haeseleer, W. (2013) 'Impact of the German nuclear phaseout on Europe's electricity generation-A comprehensive study', Energy Policy, 60, pp. 251-261. doi: 10.1016/j.enpol.2013.05.026.

Buchan, D. (2012) The Energiewende - Germany's gamble. Oxford (SP 26).

Bundesverband der Energie- und Wasserwirtschaft (BDEW) (2015) Erneuerbare Energien und das EEG: Zahlen, Fakten, Grafiken. Berlin. Available at: https://www.bdew.de/internet.nsf/id/20150511-oenergie-info-erneuerbare-energien-und-das-eeg-zahlen-fakten-grafiken-2015-de/\$file/Energie-Info_ Erneuerbare_Energien_und_das_EEG_2015_11.05.2015_final.pdf (Accessed: 12 February 2015). 
Busch, H. and McCormick, K. (2014) 'Local power: exploring the motivations of mayors and key success factors for local municipalities to go 100\% renewable energy', Energy, Sustainability and Society, 4(5), pp. 1-15.

Dempsey, J. (2012) 'Merkel Pays a Price for Her Energy Policy', The New York Times, 28 May.

Eddy, M. and Reed, S. (2013) 'Germany's Effort at Clean Energy Proves Complex', The New York Times, 18 September. Available at: http://www.nytimes.com/2013/09/19/world/europe/germanys-effort-at-cleanenergy-proves-complex.html (Accessed: 29 October 2015).

Energiekonzept für eine umweltschonende, zuverlässige und bezahlbare Energieversorgung 2010. Available at: http://www.bundesregierung.de/ContentArchiv/DE/Archiv17/_Anlagen/2012/02/ energiekonzept-final.pdf?_blob=publicationFile\&v=5 (Accessed: 5 November 2015).

Ethics Commission for a Safe Energy Supply (2011) Germany's energy transition: A collective project for the future.

Federal Ministry of Economics and Technology (BMWi) (2015) Zeitreihen zur Entwicklung der erneuerbaren Energien in Deutschland: unter Verwendung von Daten der Arbeitsgruppe Erneuerbare Energien-Statistik. Available at: http://www.erneuerbare-energien.de/EE/Redaktion/DE/Downloads/ zeitreihen-zur-entwicklung-der-erneuerbaren-energien-in-deutschland-19902014. pdf;jsessionid=DC9259CCB4A0925B184FAEBACFBC6380?_blob=publicationFile\&v=5.

Federal Ministry of Economics and Technology (BMWi) and Federal Ministry for the Environment, Nature Conservation and Nuclear Safety (BMU) (2010) Energy Concept: for an Environmentally Sound, Reliabel and Affordable Energy Supply. Berlin. Available at: http://www.bmwi.de/English/Redaktion/Pdf/energyconcept, property=pdf, bereich=bmwi,sprache=en, rwb=true.pdf.

Friedman, T. (2015) 'Germany, the Green Superpower', The New York Times, 5 May.

Helm, D. (2014) 'The European framework for energy and climate policies', Energy Policy, 64, pp. 29-35. doi: 10.1016/j.enpol.2013.05.063.

Hirschhausen, C. von (2014) 'The German "Energiewende": An Introduction', Economics of Energy \& Environmental Policy, 3(2) (12pp). doi: 10.5547/2160-5890.3.2.chir.

International Energy Agency (2013) Germany: 2013 Review. Paris (Energy Policies of IEA Countries). Available at: https://www.iea.org/publications/freepublications/publication/Germany2013_free.pdf (Accessed: 29 October 2015).

Jenssen, T., König, A. and Eltrop, L. (2014) 'Bioenergy villages in Germany: Bringing a low carbon energy supply for rural areas into practice', Renewable Energy, 61, pp. 74-80.

Kemfert, C. (2013) The battle about electricity: Myths, power and monopolies. Hamburg: Murmann. Krause, F., Bossel, H. and Müller-Reißmann, K.-F. (1980) Energie-Wende: Wachstum und Wohlstand ohne Erdöl und Uran. Ein Alternativ-Bericht des Öko-Instituts, Freiburg. Frankfurt.

Kunze, C. (2012) Soziologie der Energiewende: Erneuerbare Energien und die Transition des ländlichen Raums. Hannover: Ibidem-Verlag. 
Lehr, U., Ulrich, P., Lutz, C., Thobe, I., Edler, D., O'Sullivan, M., Simon, S., Naegler, T., Pfenning, U., Peter, F., Sakowski, F. and Bickel, P. (2015) Beschäftigung durch erneuerbare Energien in Deutschland: Ausbau und Betrieb, heute und morgen. Berlin (DIW Berlin: Politikberatung kompakt 101). Available at: http:// www.diw.de/documents/publikationen/73/diw_01.c.510565.de/diwkompakt_2015-101.pdf (Accessed: January 2016).

Morris, C. (2014) 'Germany's Energiewende', in Clark, W.W. (ed.) Global sustainable communities handbook: Green design technologies. Amsterdam: Butterworth-Heinemann an imprint of Elsevier, pp. 105-113.

Moss, T., Gailing, L., Kern, K., Naumann, M. and Röhring, A. (2013) Energie als Gemeinschaftsgut? Anregungen für die raumwissenschaftliche Energieforschung. Erkner (Working paper 50). Available at: www.irs-net.de/download/wp_gemeinschaftsgut_energie.pdf.

Moss, T., Becker, S. and Naumann, M. (2014) 'Whose energy transition is it, anyway? Organisation and ownership of the Energiewende in villages, cities and regions', Local Environment, doi:

10.1080/13549839.2014.915799

Negro, S.O and Hekkert, M.P. (2008) 'Explaining the success of emerging technologies by innovation system functioning: the case of biomass digestion in Germany', Technology Analysis \& Strategic Management, 20(4), pp. 465-482.

Nicola, S. (2013) 'End of Atomic Age Seen as Merkel's Biggest Headache Now', Bloomberg Business, 24 September. Available at: http://www.bloomberg.com/news/articles/2013-09-23/end-of-atomic-ageseen-as-merkel-s-biggest-headache-now (Accessed: 29 October 2015).

Nicola, S. (2015) 'Four Lessons Obama Should Learn from Merkel's Energy Revolution', Bloomberg Business, 5 August. Available at: http://www.bloomberg.com/news/articles/2015-08-05/four-lessonsobama-should-learn-from-merkel-s-energy-revolution (Accessed: 29 October 2015).

Nordensvärd, J. and Urban, F. (2015) 'The stuttering energy transition in Germany: Wind energy policy and feed-in tariff lock-in', Energy Policy, 82, pp. 156-165. doi: 10.1016/j.enpol.2015.03.009.

Pape, C., Gerhardt, N., Härtel, P., Scholz, A., Schwinn, R., Drees, T., Maaz, A., Sprey, J., Breuer, C., Moser, A., Salier, F., Reuter, S. and Müller, T. (2014) Roadmap Speicher: Bestimmung des SPeicherbedarfs in Deutschland im europäischen Kontext und Ableitung von technisch-ökonomischen sowie rechtlichen Handlungsempfehlungen für die SPeicherförderung. Endbericht.

Rhys, J. (2013) Current German Energy Policy - the "Energiewende": A UK and climate change perspective (Oxford Energy Comment).

Rich, H. (2013) 'Germany's Green Energy Disaster: A Cautionary Tale for World Leaders', Forbes, 14 March. Available at: http://www.forbes.com/sites/realspin/2013/03/14/germanys-green-energydisaster-a-cautionary-tale-for-world-leaders/print/ (Accessed: 30 October 2015).

Rosenkranz, G., Fücks, R. and Landgrebe, D. (2014) Energiewende 2.0: Aus der Nische zum Mainstream. (Ökologie, 36). Berlin: Heinrich-Böll-Stiftung.

Sachverständigenrat für Umweltfragen (SRU) (2011) Wege zur 100\% erneuerbaren Stromversorgung. Berlin (1). 
Sagebiel, J., Müller, J.R. and Rommel, J. (2014) 'Are consumers willing to pay more for electricity from cooperatives? Results from an online Choice Experiment in Germany', Energy Research \& Social Science, 2, pp. 90-101.

Scheer, H. (2007) Energy autonomy: The economic, social and technological case for renewable energy. London: Earthscan. Available at: http://site.ebrary.com/lib/academiccompletetitles/home.action.

Techert, H., Niehues, J. and Bardt, H. (2012) 'Verteilungswirkungen des Erneuerbare-Energien-Gesetzes', Wirtschaftsdienst, 92(8), pp. 507-519. doi: 10.1007/s10273-012-1413-0.

Töpfer, K. and Bachmann, G. (2013) Kostenschnitt für die Energiewende: Die Neuordnung der Stromkosten ist die Voraussetzung für die Reform der Energiepolitik. Berlin.

trend:research and Leuphana Universität Lüneburg (2013) Definition und Marktanalyse von Bürgerenergie in Deutschland. Bremen/Lüneburg.

Zeng, Z., Yang, H., Zhao, R. and Cheng, C. (2013) 'Topologies and control strategies of multi-functional grid-connected inverters for power quality enhancement: a comprehensive review', Renewable and Sustainable Energy Reviews, 24, pp. 223-270. 